Polish Journal of Ecology

Pol. J. Ecol. (2014) 62: 307-321

Regular research paper

Kinga KOSTRAKIEWICZ-GIERAŁT

Department of Plant Ecology, Institute of Botany, Jagiellonian University, Lubicz str. 46, 31-512 Kraków, Poland, e-mail: kinga.kostrakiewicz@uj.edu.pl

\title{
THE VARIABILITY OF SELECTED FEATURES OF GLADIOLUS IMBRICATUS L. IN RELATION TO SUCCESSIVE STAGES OF MEADOW COMMUNITIES FOLLOWING THE MOWING CESSATION
}

\begin{abstract}
Molinietum caeruleae meadows belong to the most endangered plant communities in Central Europe, nowadays suffering due to the lack of management. The land abandonment promotes strong secondary expansion of macroforbs, sedges or willows, contributing to decrease of the species diversity. In light of these findings very interesting seems to be the evaluation of the variability of features of populations of rare meadow species. In Poland one of strictly protected plant is Gladiolus imbricatus L. It is a tuberous, clonal plant with sword-like leaves and tall stalks bearing purple flowers collected in one-sided inflorescence.

The studies of spatio-temporal variability of selected features of subpopoulations of Gladiolus imbricatus were carried out in the years 20092011 in Kraków-Kostrze (Southern Poland) in patches of Molinietum caeruleae with different species composition. In Patch I chiefly occurred small meadow species, Patch II was prevailed by shrub willow, Patch III was dominated by tallgrowing macroforbs, Patch IV was characterized by substantial share of large-tussock grasses, while Patch V was overgrown by tall rhizomatous grass Phragmites communis. The plant canopy height and ground moisture raised from Patch I, via Patches II, III and IV, to Patch V. Moreover, in all sites the above mentioned parameters increased moderately in consecutive seasons.

The decline of abundance of subpopulations observed in the consecutive years and in the successive patches might be caused by a mortality of
\end{abstract}

individuals, a physical damage of tubers, as well as a prolonged dormancy of genets. The structure of developmental stages were similar in consecutive years but differed significantly among Patches. The increasing trend toward senility noted in successive sites could be an effect of lack of microsites suitable for seedling recruitment or absence of vegetative regeneration. The dimensions of leaf blades, flowering stalks and inflorescences remained similar in the subsequent seasons, but they augmented significantly in the successive patches. The length and the width of capsules did not change significantly between seasons and sites.

Concluding, it might be assumed, that the perspectives for survivability of subpopulations diminish gradually from Patch I, via Patches II, III and IV to Patch V. Simultaneously, it should be pointed out that prospects for persistence in each place steadily decrease in effect of continuous deterioration of site conditions.

KEY WORDS: capsule, flowering stalk, Gladiolus imbricatus, inflorescence, leaf blade, Molinietum caeruleae, threatened species

\section{INTRODUCTION}

The humid and wet meadows belong to the most endangered plant communities in Central Europe (D en isiuk 1992). Phytocoenoses included to group of Molinia meadows 
and classified as associations of the Molinion alliance are listed among other protected habitats in the Annex I Habitat Directive (Council Directive 92, Council Directive 97) and it is included in the net NATURA 2000 (Interpretation 2003). The phenomenon of diminishing of Molinietum caeruleae patches is observed in entire Central Europe (Fuller 1987, Green 1990, Prah 1993, Joyce and Wade 1998, Muller 2002, Rosenthal 2010, Krause et al. 2011). The patches of wet meadows reduced due to large scale land reclamation in the 1950s and 1960s, nowadays suffer due to the lack of management. The cessation of mowing promotes strong secondary succession toward tall forb or shrub communities. The rapid spread of macroforbs, large-tussock grasses and sedges, as well as willows affects in diminishing light availability, the reducing of moss cover, as well as the increase of litter deposition. The strong expansion of aforementioned plants contributes to habitat fragmentation, leading directly to the replacing of the specialist species by the generalist ones and the decrease of the species diversity.

In light of these findings very interesting seems to be the evaluation of the variability of features of meadow species populations in course of secondary succession. Particularly valuable are the investigations carried out in populations of threatened species, providing a basis for effective protection programs. So far such studies were conducted in populations of several taxa such as: Dactylorhiza incarnata (L.)Soó (Zeleznaya 2009, Schautzer et al. 2011), Iris sibirica L. (Kostrakiewicz 2007, 2008), Gentiana pneumonanthe L. (Oostermeijer et al. 1994, 1996, KostrakiewiczGierałt 2013), Ligularia sibirica (L.) Cass. (Heinken-Šmídová and Münzbergová 2012), as well as Scorzonera humilis L. (Colling et al. 2002).

Although, the above mentioned issue enjoys much interest among ecologists, the further studies are strongly needed. Therefore, the studies of the temporal and spatial variability of selected features of subpopulations of threatened species, Gladiolus imbricatus in relation to diverse light availability and soil humidity were performed. The detailed goals concentrated on assessment: (1) the abun- dance and developmental structure of populations; (2) the structure of size of individuals based on dimensions of leaf blades; (3) the structure of size of generative individuals based on the height of flowering stalk, the length of inflorescences; (4) the dimensions of fruits.

\section{STUDY SPECIES}

The sword lily Gladiololus imbricatus L. is a tuberous, clonal plant. The vegetative propagation consists of production of daughter tubers and/or tubercules. Young plants regenerating from them resemble seedlings in their morphology and size (Klimešová and Klimeš 2006). The genets of Gladiololus imbricatus form sword-like leaves and tall stalks bearing purple flowers collected in onesided inflorescence. The fruit is a slightly inflated capsule, which opens up in three parts, revealing numerous wind-dispersed seeds (Cantor and Tolety 2011). The area of distribution of this taxon covers Central and Eastern Europe, the Mediterranean, Caucasia and West Siberia (Meussel et al. 1965). The populations of sword lily occur in termophilous oak forests Potentillo albae-Quercetum, humid meadows from the Molinion alliance (Piękoś-Mirkowa and Mirek 2006), oats and barley fields (Kropač and Mochnacký 2009), as well as some anthropogenic habitats e.g. Calamagrostis epigejos- and Carex brizoides phytocoenoses (Falkowski 2002). Gladiolus imbricatus is threatened in entire Eastern and Central Europe (Sch nittler and Günther 1999). This species is enlisted in The Red List of Vascular Plants in Czech Republik (Holub and Proházka 2000), Estonia (Lilleleht 1998), Hungary (Király 2007), Latvia (Andrušaitis 2003) and Switzerland (Moser et al. 2002). In Poland it belongs to strictly protected taxa (Rozporządzenie. 2012), included to regional 'red lists' of threatened vascular plant species (Nowak et al. 2008, Głowacki et al. 2003, Jackowiak et al. 2007, JakubowskaGabara and Kucharski 1999, Kącki et al. 2003). On the basis of the analysis of regional 'red lists' Gladiolus imbricatus is considered as vulnerable in territory of Poland (Kopeć and Hajduk-Michalska 2012). 


\section{STUDY AREA}

The study area was set in Kostrze district, located on the western edge of Kraków, south of the Vistula River (Southern Poland). The patches of Molinietum caeruleae occurring in this locality are remnants of the vast meadows, which existed along the Vistula River from Czernichów to the Niepołomice Primeval Forest (Zarzycki 1958). The investigations were conducted in unmanaged patches $\mathrm{Mo}$ linietum and characterized by various species composition and habitat conditions (Fig. 1):

- Patch I measured ca $1700 \mathrm{~m}^{2}$. It was dominated by species creating shallowly rooted rhizomes or stolons and delicate, erect or procumbent stems (i.e. Lotus corniculatus L., Lathyrus pratensis L., Lysimachia vulgaris L.). The low-statured species intercept very low amount of irradiance, that contributes to strong insolation of the ground surface and fast evaporation of water from the soil area.

- Patch II achieved $1500 \mathrm{~m}^{2}$. It was overgrown by Salix repens var. rosmarinifolia (L.) Wimm. \& Grab. forming creeping, procumbent stems and low-growing branches. The wide leaf canopy of willows decreases the amount of solar radiation reaching to the soil area and prevents soil surface from desiccation.
- Patch III covered an area of $1500 \mathrm{~m}^{2}$ and was prevailed by tall-growing macroforbs such as Serratula tinctoria L., Filipendula ulmaria (L.) Maxim. and Sanguisorba officinalis $\mathrm{L}$. The wide leaf canopy of aforementioned species diminishes the amount of light reaching to the soil area and assures the substantial moisture of ground.

- Patch IV reached about $1450 \mathrm{~m}^{2}$. It was dominated by large-tussock grasses Deschampsia caespitosa (L.) P.Beauv. and Molinia caerulea (L.) Moench. The high, closely packed shoots, as well as the big, compact tussocks partly overshadow the neighbouring plants, while the hummocksand-hollows micro-topography leads to the prolonged water stagnation in spring and the substantial moisture of soil surface in summer.

- Patch V covered ca $1800 \mathrm{~m}^{2}$. It was overgrown by large, wide-spreading grass Phragmites communis (Cav.)Trin. ex Steud. The considerable height of vegetation contributes to the strongly decrease of the amount of solar radiation, that is available for adjacent plants. Moreover the substantial accumulation of necromass maintains great humidity of soil during whole growing season.

Table 1. The habitat characteristics in sites with different habitat conditions in the years 2009-2011.

\begin{tabular}{lcccccc}
\hline & Year & Patch I & Patch II & Patch III & Patch IV & Patch V \\
\hline \multirow{2}{*}{$\begin{array}{l}\text { The average height of } \\
\text { vascular plants (cm)* }\end{array}$} & 2009 & 43.5 & 67.6 & 51.4 & 82.8 & 120.7 \\
& 2011 & 46.2 & 69.1 & 55.2 & 85.9 & 124.6 \\
\hline \multirow{2}{*}{$\begin{array}{l}\text { The average cover of } \\
\text { vascular plants (\%) }\end{array}$} & 2009 & 94.5 & 94.8 & 95.1 & 95.3 & 100.0 \\
& 2010 & 95.9 & 96.4 & 97.1 & 98.2 & 100.0 \\
\hline & 2009 & 2.8 & 2.3 & 2.5 & 1.8 & 100.0 \\
The average bryo- & 2010 & 2.5 & 3.7 & 3.9 & 2.2 & 0 \\
phyte cover (\%) & 2011 & 2.9 & 2.5 & 1.3 & 0 & 0 \\
\hline & 2009 & 6.6 & 6.9 & 7.1 & 8.3 & 8.9 \\
The average ground & 2010 & 7.1 & 7.8 & 7.3 & 8.9 & 9.1 \\
humidity** & 2011 & 7.7 & 7.9 & 7.9 & 9.6 & 9.7 \\
\hline
\end{tabular}

${ }^{\star}$ calculated on the basis of 50 measurements of randomly chosen stems of different species; ${ }^{\star *}$ calculated on the basis of 50 measurements in randomly chosen sites per patch performed from April to July measured with electronic moisture sensor. Range of ground humidity:1 (dry)-10 (wet) 
Table 2. The abundance of subpopulations of Gladiolus imbricatus L. occurred in sites with different habitat conditions in the years 2009-2011.

\begin{tabular}{lccccc}
\hline Year & Patch I & Patch II & Patch III & Patch IV & Patch V \\
\hline 2009 & 47 & 39 & 33 & 25 & 22 \\
2010 & 47 & 36 & 32 & 23 & 20 \\
2011 & 45 & 33 & 31 & 21 & 17 \\
\hline
\end{tabular}

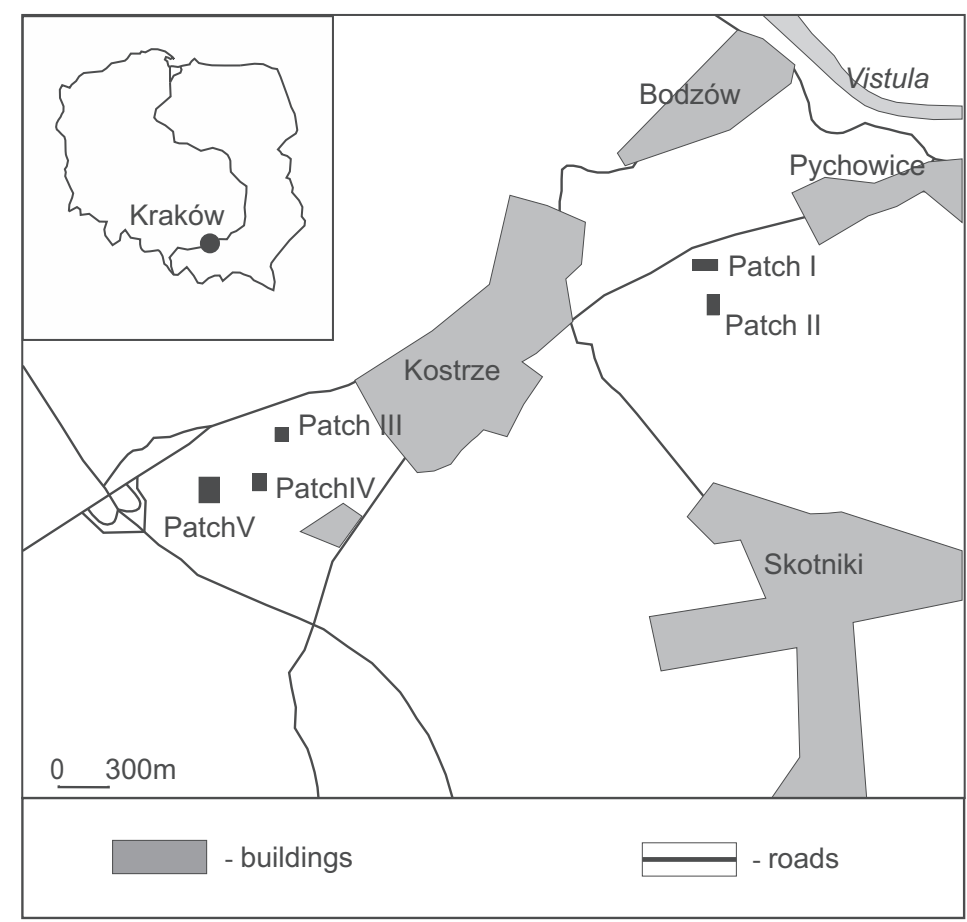

Fig. 1. The locality of study sites dominated by small meadow species (Patch I), - prevailed by willow (Patch II), overgrown by tall-growing macroforbs (Patch III), dominated by large-tussocks grasses (Patch IV), prevailed by tall-growing rhizomatous grass (Patch V).

\section{MATERIAL AND METHODS}

The field studies were conducted in the years 2009-2011. In central part of each Patch one permanent plot measuring $15 \times$ $15 \mathrm{~m}$ was set and surrounded. The average height of vascular plants within particular Patches was evaluated on the basis of 50 measurements of randomly chosen generative stems of different species. The measurements were made using measure tape, in mid-July. The average soil moisture of studied Patches was calculated on the basis of 50 measurements of ground humidity performed using electronic sensor during the growing seasons of the years 2009, 2010 and 2011. In the each first and third week of April and in the first week of May, June and July 10 measurements were performed in randomly chosen sites. The detailed habitat conditions in stud- ied patches in consecutive years are given in Table 1.

Each year the number of seedlings, juvenile individuals (one leaf), vegetative adults (two or more leaves) and generative adults (with inflorescence) of Gladiolus imbricatus were observed. Moreover in each individual, the following parameters were measured: (1) the length of the longest leaf blades; (2) the width of the longest leaf blades at $1 / 2$ of their length; (3) the height of flowering stalk from the ground level to the tip; (4) the length of inflorescences from lowermost to uppermost flower; (5) the length of all capsules; (6) the width of all capsules at $1 / 2$ of their length. The biometric measurements length/width of leaf blades, height of flowering stalks, as well as length of inflorescences were made in early July, while length/width of capsules were surveyed in mid-August. 
The chi-square statistics was applied to check whether there were the significant differences among years and patches in percentage of:

- individuals in different developmental stages,

- genets achieving various height of flowering stalks, length of inflorescences, as well as length and width of the longest leave blades,

- fruits reaching different length and width.

\section{RESULTS}

The abundance of genets diminished in consecutive years and in successive Patches (Table 2). The frequency of individuals in different developmental stages stayed constant in consecutive seasons but it varied in successive plots. The percentage of vegetative adults decreased, while the frequency of generative individuals raised gradually from Patch I, via Patches II, III and IV, to Patch V (Fig. 2). The structures of size of individuals based on the length and the width of the longest leaf blades, as well as the height of flowering stalks and the length of inflorescences not varied in consecutive years but differed substantially between sites. The values of above mentioned traits gradually raised in the successive Patches. The average length of the longest leaf achieved in Patch I from $15.9 \mathrm{~cm}$ to $16.4 \mathrm{~cm}$, whereas in Patch V it reached from $25.6 \mathrm{~cm}$ to $25.8 \mathrm{~cm}$ (Fig. 3). The mean width of the longest leaf measured from $0.99 \mathrm{~cm}$ to $1.02 \mathrm{~cm}$ in Patch I, while in Patch $\mathrm{V}$ it attained from $2.13 \mathrm{~cm}$ to $2.15 \mathrm{~cm}$ (Fig. 4). The height of flowering stalks in Patch I ranged from $54.2 \mathrm{~cm}$ to $61.9 \mathrm{~cm}$, whilst in Patch V it achieved from $104.6 \mathrm{~cm}$ to $106.2 \mathrm{~cm}$ on average (Fig. 5). The mean length of inflorescence in Patch I measured from $4.5 \mathrm{~cm}$ to $5.4 \mathrm{~cm}$, whereas in Patch V it attained from $7.9 \mathrm{~cm}$ to $9.9 \mathrm{~cm}$ (Fig 6). The dimensions of capsules remained constant in the consecutive years and sites. The length of fruits reached from $0.99 \mathrm{~cm}$ to $1.08 \mathrm{~cm}$ (Fig. 7), while their width achieved from $0.82 \mathrm{~cm}$ to $0.91 \mathrm{~cm}$ on average (Fig. 8).

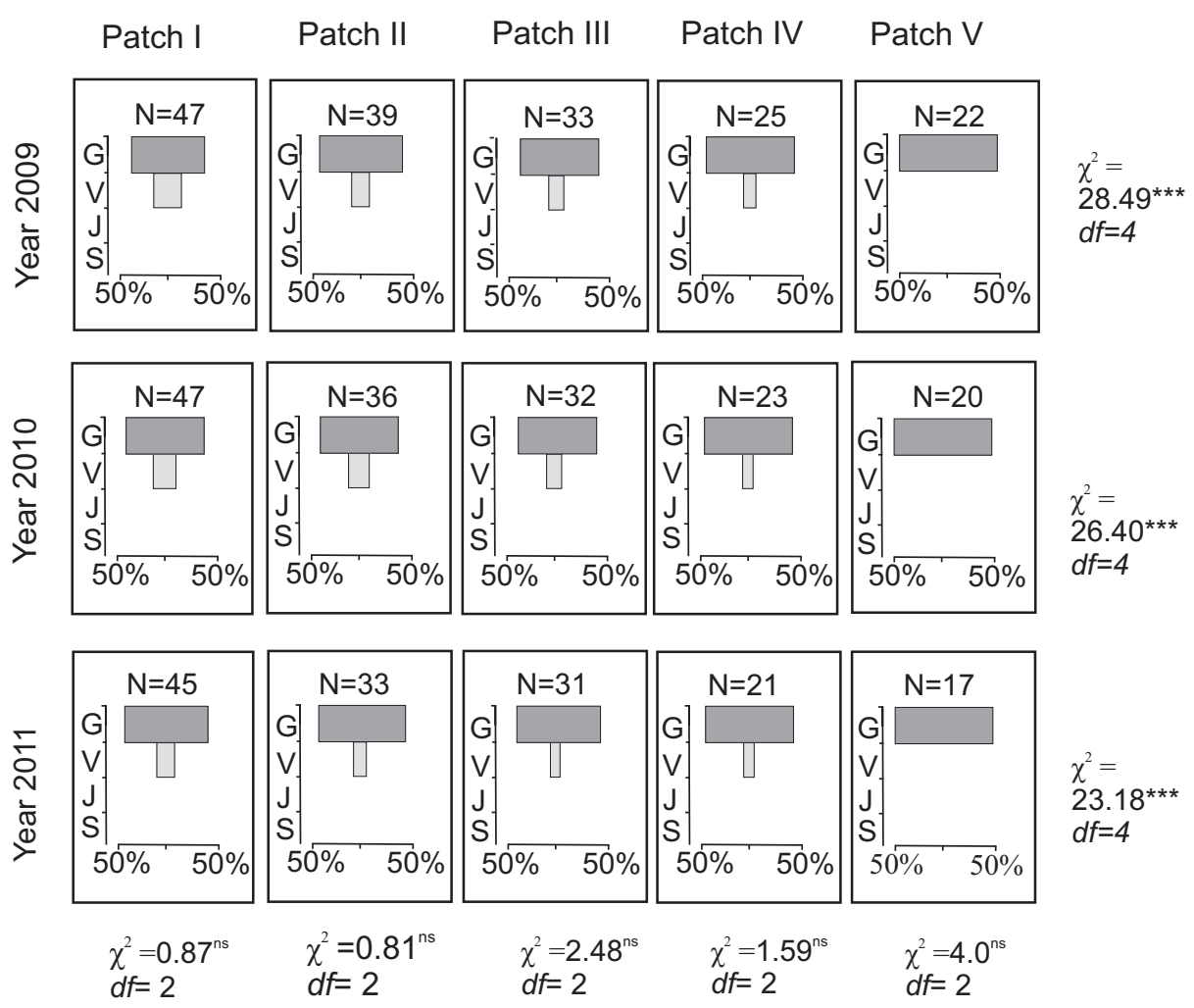

Fig. 2. The developmental structure of populations located in in sites with different habitat conditions in the years 2009-2011. Abbreviations and symbols: S - seedlings, J - juvenile individuals, V - vegetative adults, $\mathrm{G}-$ generative adults. Asterisks mean statistically significant differences (the chi square test) ${ }^{* * *} P<0.001,{ }^{n s}-$ not significant differences. 

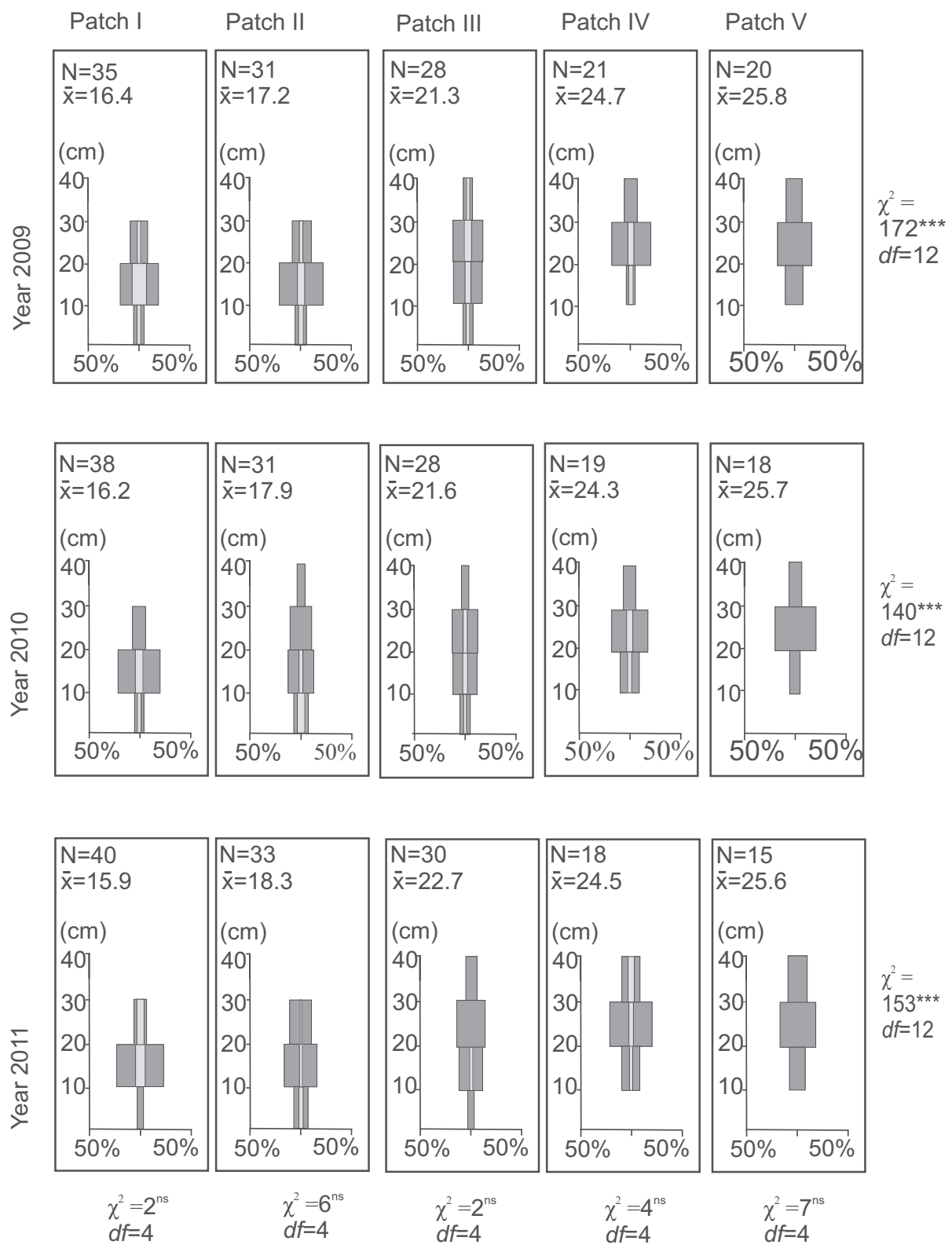

- The vegetative adults

- The generative adults

Fig. 3. The structure of size of individuals based on length of the longest leaf blades in sites with different habitat conditions in the years 2009-2011. Abbreviations and symbols: Asterisks mean statistically significant differences (the chi square test) ${ }^{* *} P<0.001,{ }^{\text {ns }}$ - not significant differences. 

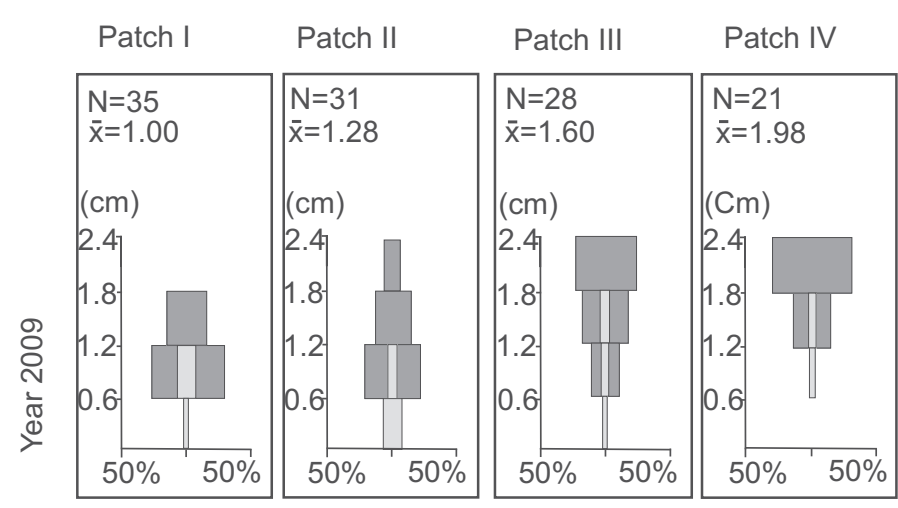

Patch V
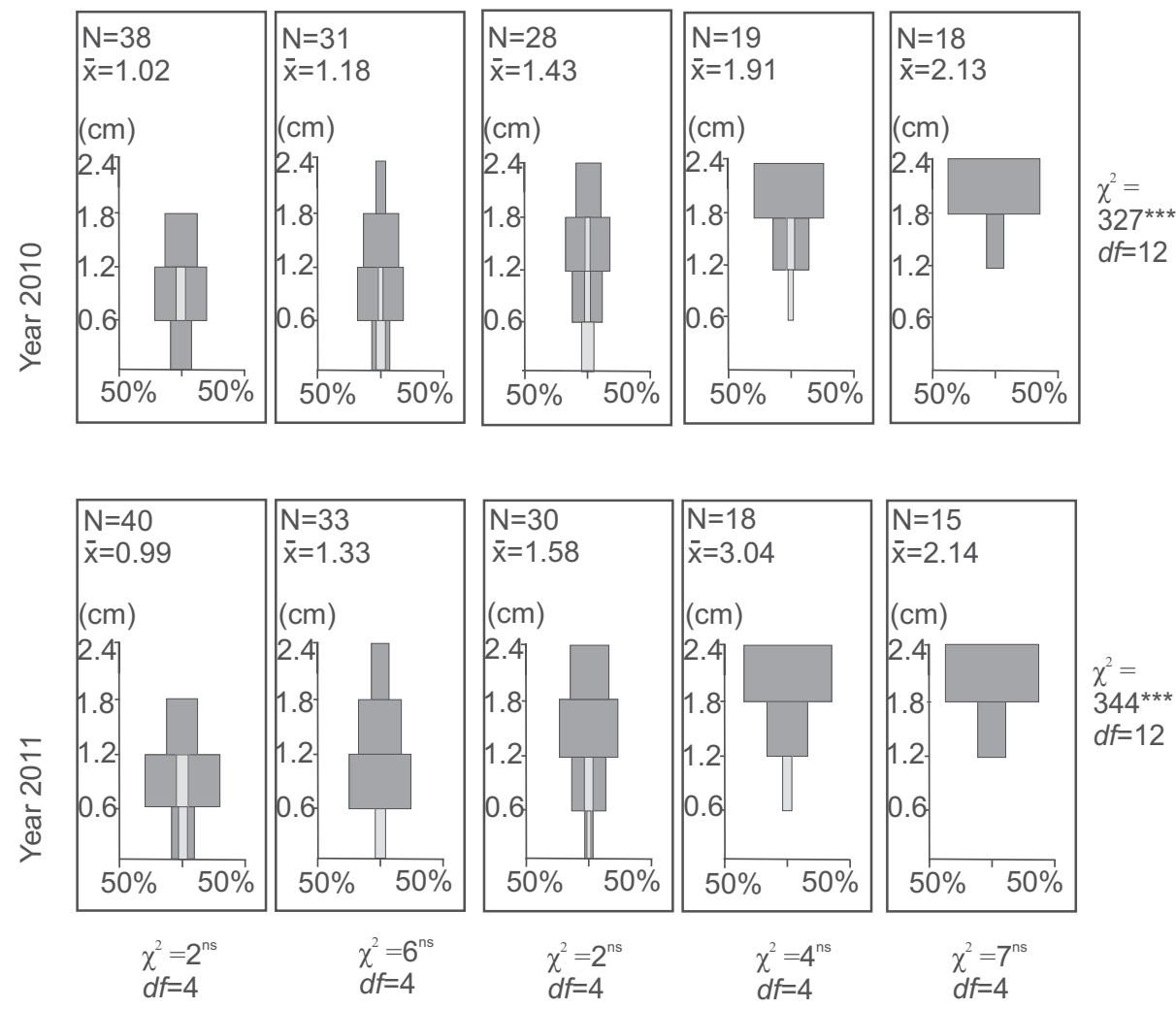

- The vegetative adults

- The generative adults

Fig 4. The structure of size of individuals based on width of the longest leaf blades in sites with different habitat conditions in the years 2009-2011. Abbreviations and symbols as in Fig. 3. 

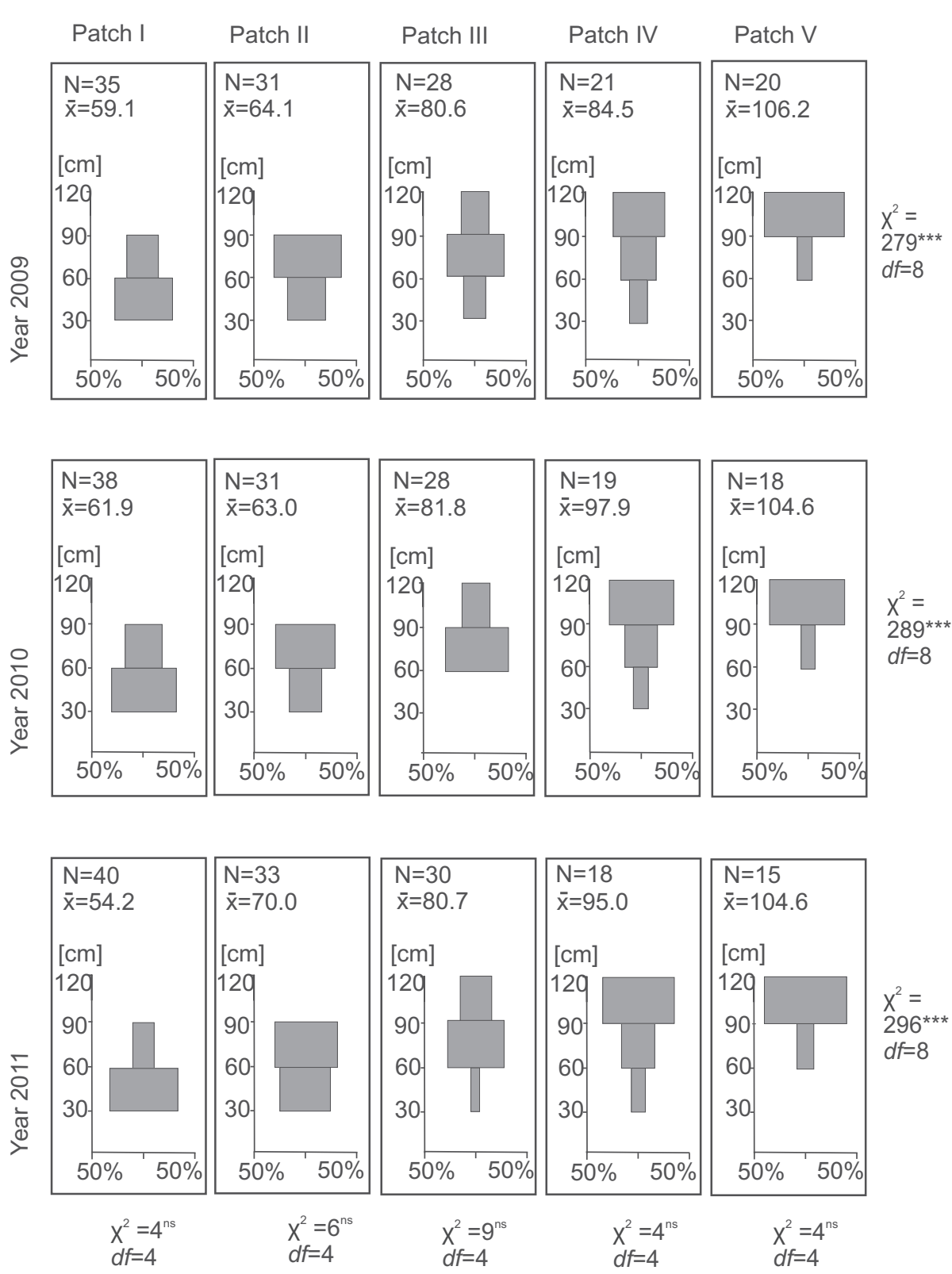

- The vegetative adults

- The generative adults

Fig. 5. The structure of size of generative individuals based on height of flowering stalks in sites with different habitat conditions in the years 2009-2011. Abbreviations and symbols as in Fig. 3. 

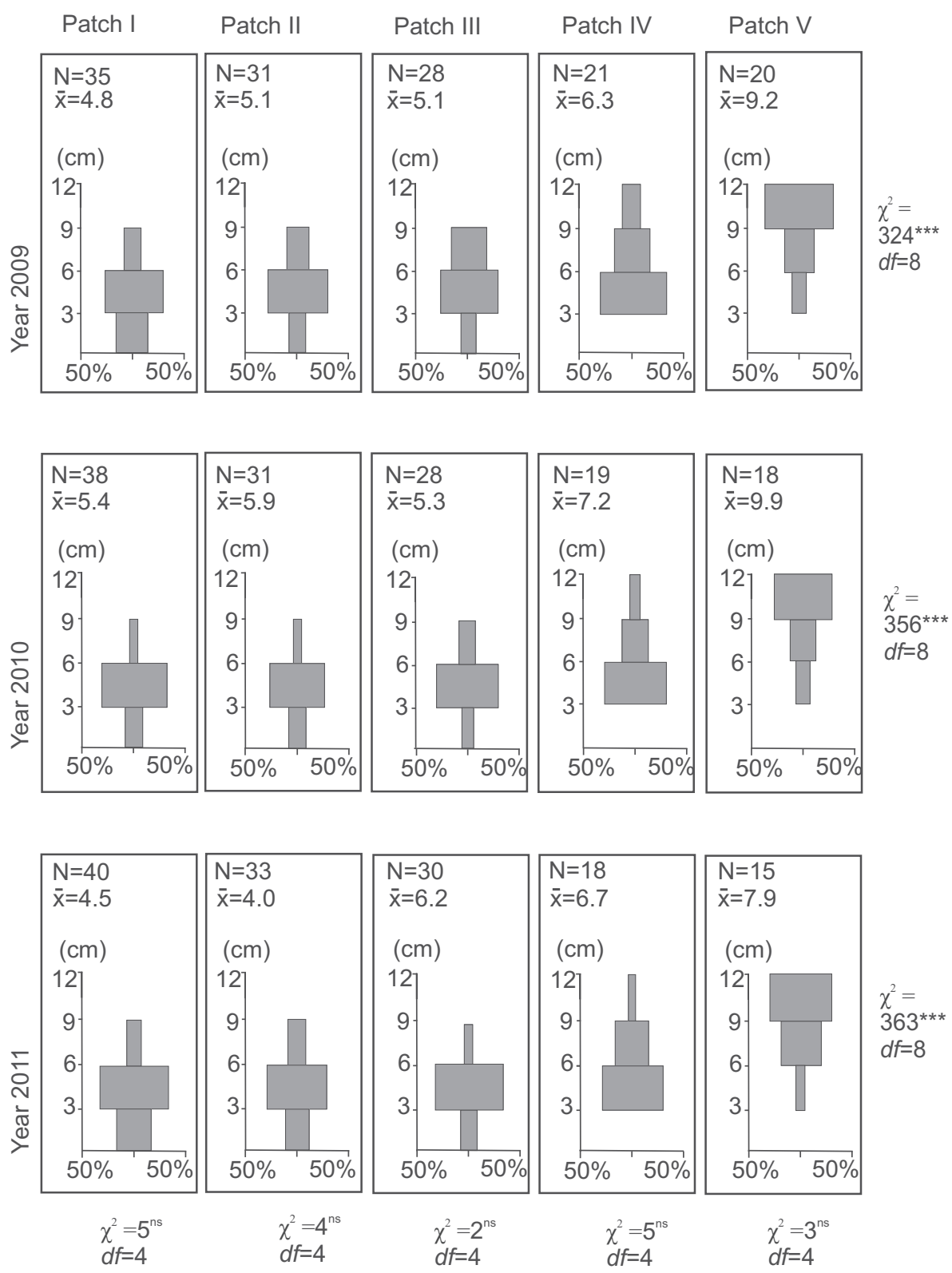

- The vegetative adults

- The generative adults

Fig. 6. The structure of size of generative individuals based on length of inflorescences in sites with different habitat conditions in the years 2009-2011. Abbreviations and symbols as in Fig. 3. 

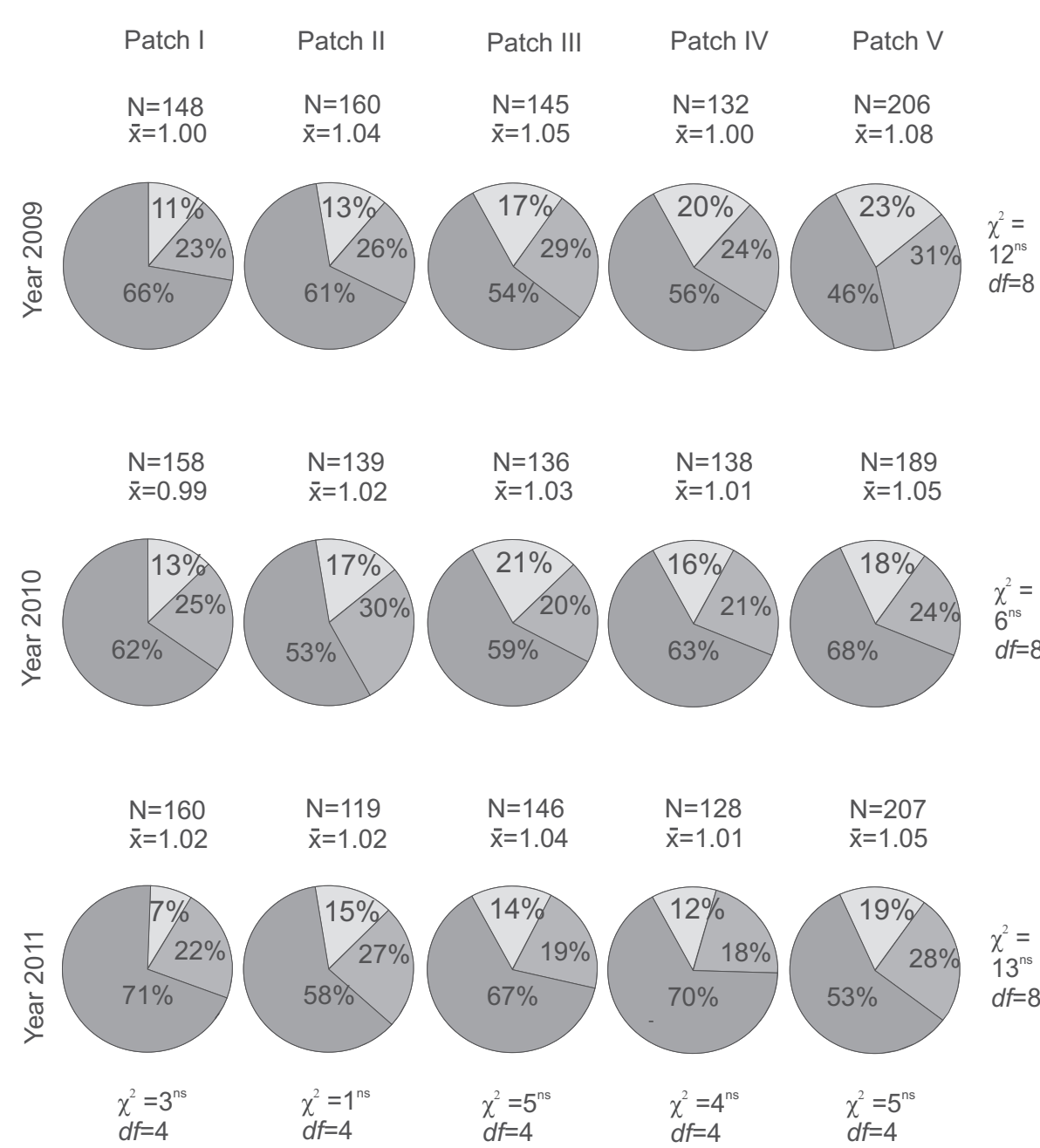

Lenght of capsules

$0.31-0.60 \mathrm{~cm}$

$0.61-0.90 \mathrm{~cm}$

$0.91-1.20 \mathrm{~cm}$

Fig. 7. The frequency of capsules with different length in sites with different habitat conditions in the years 2009-2011. Abbreviations as in Fig. 3. 


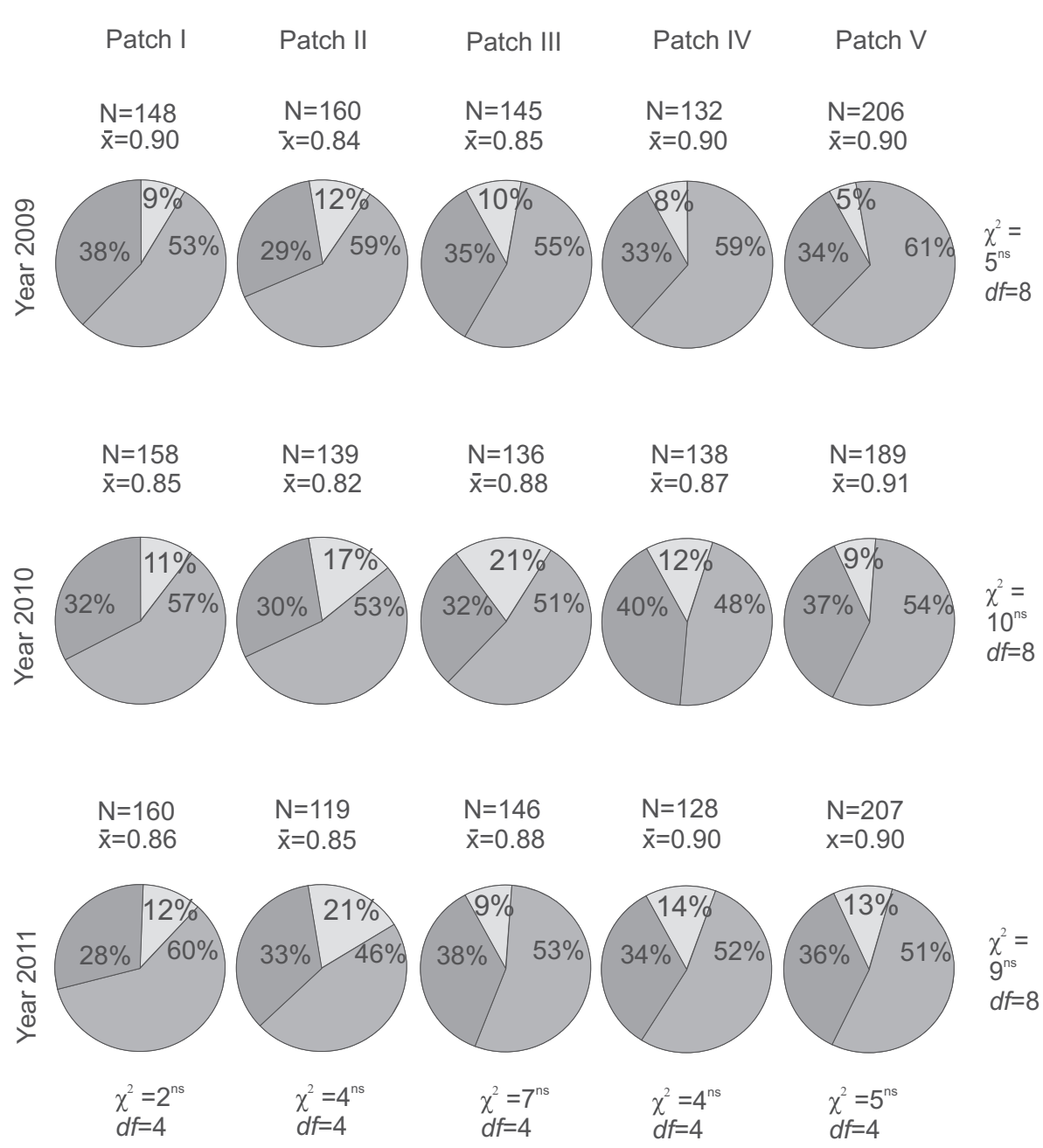

Width of capsules

Fig. 8. The frequency of capsules with different width in sites with different habitat conditions in the years 2009-2011. Abbreviations as in Fig.3. 


\section{DISCUSSION}

The observed gradually decrease of abundance of Gadiolus imbricatus subpopulations in the consecutive years and in the successive patches might be an effect of the mortality of individuals caused by the natural process of senescence, as well as the physical damage of tubers by rodents already recorded by Cantor and Tolety (2011). The diminishing of number of genets could be also a result of vegetative dormancy, widely documented in the populations of sword lily (Kubikova and Zeidler 2011 and literature cited here), as well as in the several other species (Hutchings 1987, Lesica and Steele 1994, Oostermaier et al. 1996, Brzosko 2002, Sheffers on et al. 2001, Kéry and Greg 2004). The dormancy of individuals of Gladiolus imbricatus might be triggered by the raising water table level in successive plots, as well as in consecutive years. Simultaneously, it should be added that effect of temporal inundations on vegetative dormancy was already observed in populations of Gentiana pneumonanthe (Oostermeijer et al. 1992). The dormancy of sword lily genets might be also induced by diminishing light availability in effect of the gradually increase of height of standing vegetation and the successional closure of plant canopy in subsequent years and in successive patches. The strong positive correlation between dormancy and shading was found in the populations of terrestrial orchids (Sheffers on et al. 2005).

The increasing trend toward senescence of subpopulations, noted in the successive patches, is an effect of lack of genets in early ontogenic stages. Such phenomenon is due to diminishing number of the competitor-free microsites suitable for recruitment and survival of seedlings. The advantageous effect of the gaps in plant canopy and litter on the rejuvenilization of the Gladiolus imbricatus populations was showed repeatedly (Kose and Moora 2005, Moora et al. 2007, Jõgar and Moora 2008). Simultaneously, it should be pointed out, that absence of genets in early ontogenic stages might suggests the lack of vegetative regeneration. The rarity of clonal propagation in tuberous plants was noted by Klimeš et al. (1997).

The obtained results documenting the lack of the temporal variability and the con- siderable spatial diversity of the length of leaf blades are consistent with the observations carried out in populations of Iris sibirica (Kostrakiewicz 2008). The significant increase of the leaf length in response to the substantial shading by the tall-growing neighbors was also observed in populations of Dactylorhiza majalis (Rchb.) P.F. Hunt \& Summerh (Janečková et al. 2006). Moreover, the rise of the leaf length and width in result of the decreasing irradiance level was previously observed by Xue et al. (2008), as well as Rozendaal et al. (2006). According to aforementioned authors such phenomenon might improve the efficiency of light interception and thus maximize photosynthetic capacity.

The performed investigations, showing the absence of the temporal variability and the considerable spatial diversity of height of flowering stalks are consistent with observations carried out in populations of Iris sibirica (Kostrakiewicz 2008), Trollius europaeus L. (Kostrakiewicz 2009) and Gentiana pneumonanthe (KostrakiewiczGierałt 2013). Furthermore, the gradually increase of height of flowering stalks in successive patches corresponds with findings of Kubikova and Zeidler (2011) demonstrating the occurrence of higher generative shoots of Gladiolus imbricatus in abandoned meadows, than in managed patches. Similar phenomenon was documented in populations of other perennials inhabiting wet meadows such as Cirsium rivulare (Jacq.) All. (Kotańska 1986-1987), C. oleraceum (L.) Scop (Kotańska 1986-1987), Dactylorhiza majalis (Jan ečková 2006), as well as D. incarnata (Schautzer et al. 2011). According to the above mentioned authors the gradually augmentation of length of flowering shoots in vicinity of tall-growing plants may contribute to better accessibility of flowers to pollinators.

The presented studies demonstrating the lack of a temporal variability and a considerable spatial diversity of the inflorescence length are consistent with observations conducted in populations of Trollius europaeus (Kostrakiewicz 2009) and Gentiana pneumonanthe (Kostrakiewicz-Gierałt 2013). In the wide range of habitats and the large spectrum of taxa the rise of inflorescence size along shading gradient created by 
neighboring plants increases the visibility of flowers by pollinators (e.g. Firmage and Cole 1988, Schmid-Hempel and Speiser 1988, Thompson 1988, Andersson 1991, Ohara and Higashi 1994).

The observed in populations of Gladiolus imbricatus absence of temporal and spatial variability of capsule dimensions was also noted in populations of long-lived Gentiana pneumonanthe (Kostrakiewicz-Gierałt 2013). In contrary, the diversity of fruit size along the shading gradient was observed in several annuals such as Pisum sativum (Hole and Scott 1981), Helianthus annuus (Lindström et al. 2006), and Impatiens parviflora (Piskorz 2005).

To sum up, it should be concluded that the best perspectives for survivability in the colonized area has the subpopulation occurring in the place dominated by small meadow species. The weaker condition characterize the subpopulations inhabiting in patches prevailed by shrub willow species, tall-growing macroforbs, and large-tussock grasses, while the worst state shows the subpopulation from the plot overgrown by common reed grass. Simultaneously it might be concluded that prospects for persistence in each place steadily decrease in effect of continuous deterioration of site conditions.

\section{REFERENCES}

Andersson S. 1991 - Floral Display and Pollination Success in Achillea ptarmica (Asteraceae) - Holarctic Ecology, 14: 186-191.

Andrušaitis G. 2003 - Red Data Book of Latvia. Vol. 3. Vascular Plants - Institute of Biology, Riga, 691 pp.

Brzosko E. 2002 - Dynamics of island populations of Cypripedium calceolus in the Biebrza river valley (northest Poland) - Bot. J. Linn. Soc. 139: 67-77.

Cantor M., Tolety J. 2011 - Gladiolus (In: Wild Crop Relatives: Genomic and Breeding Resources: Plantation and Breeding Recources, Plantation and Ornamental Crops, Ed: Ch. Kole) - Springer-Verlag Berlin Heidelberg, pp. 133-156.

Colling G., Matthies D., Reckinger C. 2012 - Population structure and establishment of the threatened long-lived perennial Scorzonera humilis in relation to environment - J. Appl. Ecol. 39: 310-320.

Council Directive 92/43/EEC of 21 May 1992 on the Conservation of Natural Habitats and of Wild Fauna and Flora-Official Journal L 206, 22.07.1992 P, 0007-0050.

Council Directive 97/62/EC of 27 October 1997 adapting to technical and scientific progress Directive 92/43/EEC on the Conservation of Natural Habitats and of Wild Fauna and Flora-Official Journal L 305, 08.11.1887 P, 0042-0065.

Denisiuk Z. 1992 - Interaction between agriculture and nature conservation in Poland - ICUN Press, Gland, Switzerland and Cambridge, UK. Vol. 12, pp 1-162.

Falkowski M. 2002 - Nowe stanowisko Gladiolus imbricatus (Iridaceae) w dolinie środkowej Wisły [New position of Gladiolus imbricatus (Iridaceae) in the central Vistula Valley Fragm. Flor. Geobot. Polonica, 9: 369-370.

Firmage D.H., Cole F.R. 1988 - Reproductive success and inflorescence size of Calopogon tuberosus (Orchidaceae) - Am. J. Bot. 75: 1371-1377.

Fuller R.M. 1987 - The changing extent and conservation interest of lowland grasslands in England and Wales: a review of grasslands surveys 1930-84 - Biol. Conserv. 40: 281-300.

Głowacki Z., Falkowski M., Krechowski J., Marciniuk J., Marciniuk P., Nowicka-Falkowska K., Wierzba M. 2003 - Czerwona lista roślin naczyniowych Niziny Południowopodlaskiej [The red list of vascular plant of the Południowopodlaska Lowland] - Chrońmy Przyr. Ojcz. 59: 5-41 (in Polish, English summary).

Green B.H. 1990 - Agricultural intensification and the loss of habitat, species and amenity in British grasslands: a review of historical change and assessment of future prospects Grass and Forage Science, 45: 365-372.

Heinken-Šmídová A., Münzbergová Z. 2012 - Population Dynamics of the Endangered, Long-Lived Perennial Species, Ligularia sibirica - Folia Geobot. 47: 193-214.

Hole C.C., Scott P.A. 1981 - The effect of fruit shading on yield in Pisum sativum L. Ann Bot. 48: 827-835.

Holub J., Proházka F. 2000 - Red List of vascular plants of the Czech Republic - Preslia, 72: $167-186$.

Hutchings M.J. 1987 - The population biology of the early spider Orchid Ophrys sphegodes Mill. I A demographic study from 1975-1984 - J. Ecol. 75: 711-725.

Interpretation Manual of European Union Habitats EUR 25, version April 2003, European Commission, DG Environment. Nature and biodiversity.

Jackowiak B., Celka Z., Chmiel J., Latowski K., Żukowski W. 2007 - Red 
list of vascular flora in Wielkopolska (Poland) - Biodiv.Res.Conserv. 5-8: 95-127.

Jakubowska-Gabara J., Kucharski L. 1999 - Ginące i zagrożone gatunki flory naczyniowej zbiorowisk naturalnych i półnaturalnych Polski Środkowej [Endangered and threatened vascular plants in natural and seminatural communities in Central Poland] - Fragm. Flor. Geobot. Polonica, 6: 55-74.

Janečková P., Votavová K., Schödelbauerová I., Jersáková J., Kindlmann P. 2006 - Relative effects of management and environmental conditions on performance and survival of populations of a terrestrial orchid, Dactylorhiza majalis - Biol. Conserv. 129: 40-49.

Jõgar Ü., Moora M. 2008 - Reintroduction of a rare plant (Gladiolus imbricatus) population to a river floodplain - How important is meadow management? - Restor. Ecol. 16: 382-385.

Joyce C.B., Wayde P.M. 1998 - European wet grasslands: biodiversity, management and restoration - Wiley, Chichester, UK, 385 pp.

Kącki Z., Dajdok Z., Szczęśniak E. 2003 Czerwona lista roślin naczyniowych Dolnego Sląska [The red list of vascular plants of Lower Silesia] (In: Zagrożone gatunki flory naczyniowej Dolnego Śląska [Endangered vascular plants of Lower Silesia], Ed: Z. Kącki) - Instytut Biologii Roślin U. Wr. PTPP „pro Natura” Wrocław, pp. 9-65 (in Polish).

Kéry M., Greg K.B. 2004 - Demographic analysis of dormancy and survival in the terrestrial orchid Cypripedium reginane - J. Ecol. 92: 686-695.

Király G. 2007 - Red List of the Vascular flora in Hangary - Saját kiadás, Sopron, 73 pp.

Klimeš L., Klimešová J., Hendriks R., van Groenendael J. 1997 - Clonal plant architecture: a comparative analysis of form and function (In: The ecology and evolution of clonal plants, Eds: H. de Kroon, J. van Groenendael) - Backhuys Publishers, Leiden, The Netherlantds, pp. 1-29.

Klimešová J., Klimeš L. 2006 - Clo-Pla3 - database of clonal growth of plants from Central Europe - (http://clopla.butbn.cas.cz/, available June 3, 2013)

Kopeć D., Hajduk-Michalska D. 2012 How threatened is the Polish wetland flora? - Oceanol. Hydrobiol. St.. 41: 79-89.

Kose M., Moora M. 2005 - Monitoring the Wild gladiolus (Gladiolus imbricatus) population under different meadow management regimes (In: Coastal meadow management: best practice guidelines, Eds: R. Rannap, L. Briggs, K. Lotman, I. Lepik, I., V. Rannap) - Ministry of the Environment of the Republic of Estonia, Tallinn, pp. 70-71.
Kostrakiewicz K. 2007 - The effect of dominant species on numbers and age structure of Iris sibirica L. population on blue moor-grass meadow in southern Poland - Acta Bot. Soc. Pol. 76: 165-173.

Kostrakiewicz K. 2008 - Population structure of a clonal endangered plant species Iris sibirica L. in different habitat conditions - Pol. J. Ecol. 56: 581-592.

Kostrakiewicz K. 2009 - The influence of shadow created by adjacent plants on phenotypic plasticity of endangered species Trollius europaeus L. (Ranunculaceae) - Pol. J. Ecol. 57: 625-634.

Kostrakiewicz-Gierałt K. 2013 - The effect of vegetation character on abundance and structure of subpopulations of rare herb Gentiana pneumonanthe L. - Pol. J. Ecol. 61: 35-46.

Kotańska M. 1986-1987 - Coexistence of populations of Cirsium rivulare (Jacq.) All. and C. oleraceum (L.) Scop. in the Wierzbanówka valley in the Wieliczka Foothills. I. Conditions of occurrence and spatial structure - Fragm. Flor. Geobot. 31-32: 395-421.

Krause B., Culmsee H., Wesche K., Bergmeier E., Leuschner Ch. 2011 - Habitat loss of floodplain meadows in north Germany since the 1950 s - Biodivers. Conserv. 20: 2347-2364.

Kropač Z., Mochnacký S. 2009 - Contribution to the segetal communities of Slovakia Taiszia - J. Botany, 19: 145-211.

Kubikova P., Zeidler M. 2011 - Habitat demands and population characteristiks of the rare plant species Gladiolus imbricatus L. in the Frenštát region (NE Moravia, the Czech Republik) - Čas. Slez. Muz. Opava, 60: 154164.

Lesica P., Steele B.M. 1994 - Prolonged dormancy in vascular plants and implications for monitoring studies - Natural Areas J. 14: 209-212.

Lilleleht V. 1998 - The red data book of Estonia. Threatened plants, fungi and animals ETA - Looduskaitse Komisjon, Tartu, Estonia. 150 pp (in Estonian, English summary).

Lindström L.I., Pellegrini C.N., Aguirrezábal L.A.N., Hermández L.F. 2006 - Growth and development of sunflower fruits under shade during pre and early post-anthesis period - Field Crop Research, 96: 151-159.

Meusel H., Jäger E., Weinert E. 1965 Vergleichende Chorologie der Zentraleuropäischen Flora. Bd. I - Gustav Fisher, Jena: pp. 583, karten 258.

Moora M., Kose M., Jogar U. 2007 - Optimal management of the rare Gladiolus imbricatus in Estonian coastal meadows indicated 
by its population structure - Appl. Veg. Sci. 10: 161-168.

Moser D., Gygax A., Bäumler B., Wyler N., Palese R 2002 - Liste Rouge des fougères et plantes à fleurs menacées de Suisse - Office fédéral de l'environnement, des forêts et du paysage, Berne, Centre du Réseau Suisse de Floristique, Chambésy, Conservatoire et Jardin botaniques de la Ville de Genève, Chambésy. Série OFEFP "L'environnement pratique", $118 \mathrm{pp}$.

Muller S. 2002 - Diversity of management practices required to ensure conservation of rare and locally threatened plant species in grasslands: a case study at a regional scale (Lorraine, France) - Biodivers. Conserv. 11: 1173-1184.

Nowak A., Nowak S., Spałek K. 2008 Red list of vascular plants in Opole province - Opole Scient. Soc. Nature J. 41: 141-158.

Ohara M., Higashi S. 1994 - Effects of inflorescence size on visits from pollinators and seed set of Corydalis ambigua (Papaveraceae) - Oecologia, 98: 25-30.

Oostermaijer J.G.B, Brugman M.L, de Boer E.R., Den Nijs H.C.M. 1996 Temporal and spatial variation in the demography of Gentiana pneumonanthe, a rare perennial herb - J. Ecol. 84:153-166.

Oostermeijer J.G., Den Nijs B.J.C.M., Raijmann L.E.L., Menken S.B.J. 1992 - Population biology and management of the marsh gentian (Gentiana pneumonanthe L.), a rare species in the Netherlands - Bot. J. Linn. Soc. 108: 117-130.

Oostermaijer J.G.B., Van't Veer R., Den Nijs J.C.M. 1994 - Population structure of the rare, long-lived perennial Gentiana pneumonanthe in relation to vegetation and management in the Netherlands - J. Appl. Ecol. 31: 428-438.

Piękoś-Mirkowa H., Mirek Z., 2006 - Flora Polski. Rośliny chronione [Flora of Poland. protected plants] - Oficyna Wydawnicza Mulico, Warszawa, 417 pp. (in Polish).

Piskorz R. 2005 - The effect of oak-hornbeam diversity on flowering and fruiting of Impatiens parviflora DC - Rocz. AR Pozn. CCCLXXIII, Bot-Stec. 9:187-196.

Prah K. 1993 - Vegetational changes in a wet meadow complex, South Bohemica, Czech Republic - Folia Geobot. 40:1-13.

Rosenthal G. 2010 - Secondary succession in a fallow central European wet grassland - Flora, 205: 153-160.
Rozendaal D.M.A., Hurtado W.H., Porter L. 2006 - Plasticity of leaf traits of 38 tropical tree species in response to light; relationships with light demand and adult stature - Funct. Ecol. 20: 207-216.

Rozporządzenie Ministra Środowiska z dnia 5 stycznia 2012 r. w sprawie ochrony gai tunkowej roślin [Regulation of the Minister of Environment of 5 January 2012 on the plant species protection] Dz. U. z 2012 r., poz. 81.

Schautzer J., Fichtner A., Huckauf A., Rasran L., Jensen K. 2011 - Long-term population dynamics of Dactylorhiza incarnata (L.) Soó after abandonment and re-introduction of mowing - Flora, 206: 622-630.

Schmid-Hempel P., Speiser B. 1988 - Effects of inflorescence size on pollination in Epilobium angustifolium - Oikos, 53: 98-104.

Schnittler M., Günther K.F. 1999 - Central European vscular plants requiring priority conservation measures - an analysis from national Red Lists and distribution maps - Biodiv. Conserv. 8: 891-925.

Shefferson R.P., Kull T., Tali K. 2005 - Adult whole-plant dormancy induced by stress in long-lived orchids - Ecology, 86: 3099-3104.

Shefferson R.P, Sandercock B.K., Proper J., Beissinger S.R. 2001 - Estimating Dormancy and Survival of a Rare Herbaceous Perennial Using Mark-Recapture Models - Ecology, 82: 145-156.

Thompson J.D. 1988 - Effects of variation in inflorescence size and floral rewards on the visitation rates of traplining pollinators of $\mathrm{Ara}$ lia hispida - Evol. Ecol. 2: 65-76.

Xue J.P., Wang X., Zhang A.M., Huang X.D., He J.Q., Chang L. 2008 - Effects of shading on photosynthetic characteristics of Pinellia ternata leaves - Zhongguo Zhong Yao Za Zhi. 33: 2896-900.

Zeleznaya E.L. 2009 - Changes in the structure of Dactylorhiza incarnata (L.) S population during the overgrowing of a meadow-bog community complex in the Moscow region Russ. J. Ecol. 40: 39-43.

Zarzycki K. 1958 - Wilgotne łąki w okolicach Czernichowa i potrzeba ich ochrony $[\mathrm{Hu}-$ mid meadows in the environments of Czernichów near Cracow deserving protection] - Ochr. Przyr. 25: 49-68 (in Polish, English summary). 
